\title{
Research and Reflection on the Protection of Historical and Cultural Blocks in China and Europe Taking Jianghan Road in Hankou and Marais District in Paris as Examples
}

\author{
Yinuo Wei ${ }^{1, *}$
}

\author{
${ }^{1}$ Wuhan Textile University, Wuhan, Hubei, China \\ *Corresponding author. Email:895152673@qq.com
}

\begin{abstract}
The preservation and reformation of historical and cultural blocks has always been a concern of people in China and foreign countries. It not only bears the richest historical memory in the local area, but also reflects people's lifestyles and regional cultural characteristics in different periods. Through summarizing the strategies for preservation and reformation of the Marais District in Paris, France, and thinking about the changes in today's life patterns, this paper puts forward ideas and suggestions for the preservation and reformation of Jianghan Road, a historical and cultural district in Hankou.
\end{abstract}

Keywords: historical and cultural blocks, comparison between China and Europe, Jianghan Road in Hankou,

\section{Marais District}

\section{INTRODUCTION}

\section{A. Research background}

1) Related concepts of historical and cultural blocks: Historical and cultural blocks refer to historical sites that should be well protected under the approval of the people's governments of provinces, autonomous regions and municipalities directly under the central government. The "Relics Protection Law of the People's Republic of China" ${ }^{1}$ defines the historical and cultural blocks as: the legally protected area, which is academically called "historical site". The "Regulations on the Protection of Historical and Cultural Cities" 2 defines "historical and cultural blocks" as blocks that reflect the traditional scene or local cultural characteristics of a certain historical period, have many cultural relics and historical buildings and have a certain scale.

Around 2008, according to the "Regulations on the Protection of Historical and Cultural Cities", a collection of "historical and cultural blocks" as the main concept, including "historical urban areas" and "historical sites" and other extended concepts was initially formed. Taking Wuhan as an example, 38 cities including Wuhan, Hubei, Pingyao, Shanxi, and Nanchang, Jiangxi were approved by the State Council as the second batch of historical and cultural cities, namely "historical urban areas". According to the content of "Wuhan Historical and Cultural City Conservation Plan", ten areas with dense historical buildings including Jianghan Road and Zhongshan Avenue blocks, which can truly reflect the history and culture of Wuhan, are classified as "historical sites". Among them, Jianghan Road and Zhongshan Avenue blocks were listed as "national historical and cultural blocks" in 2015 for key protection.("Fig. 1")
2002. Cities.
Relics Protection Law of the People's Republic of China, Regulations on the Protection of Historical and Cultural 


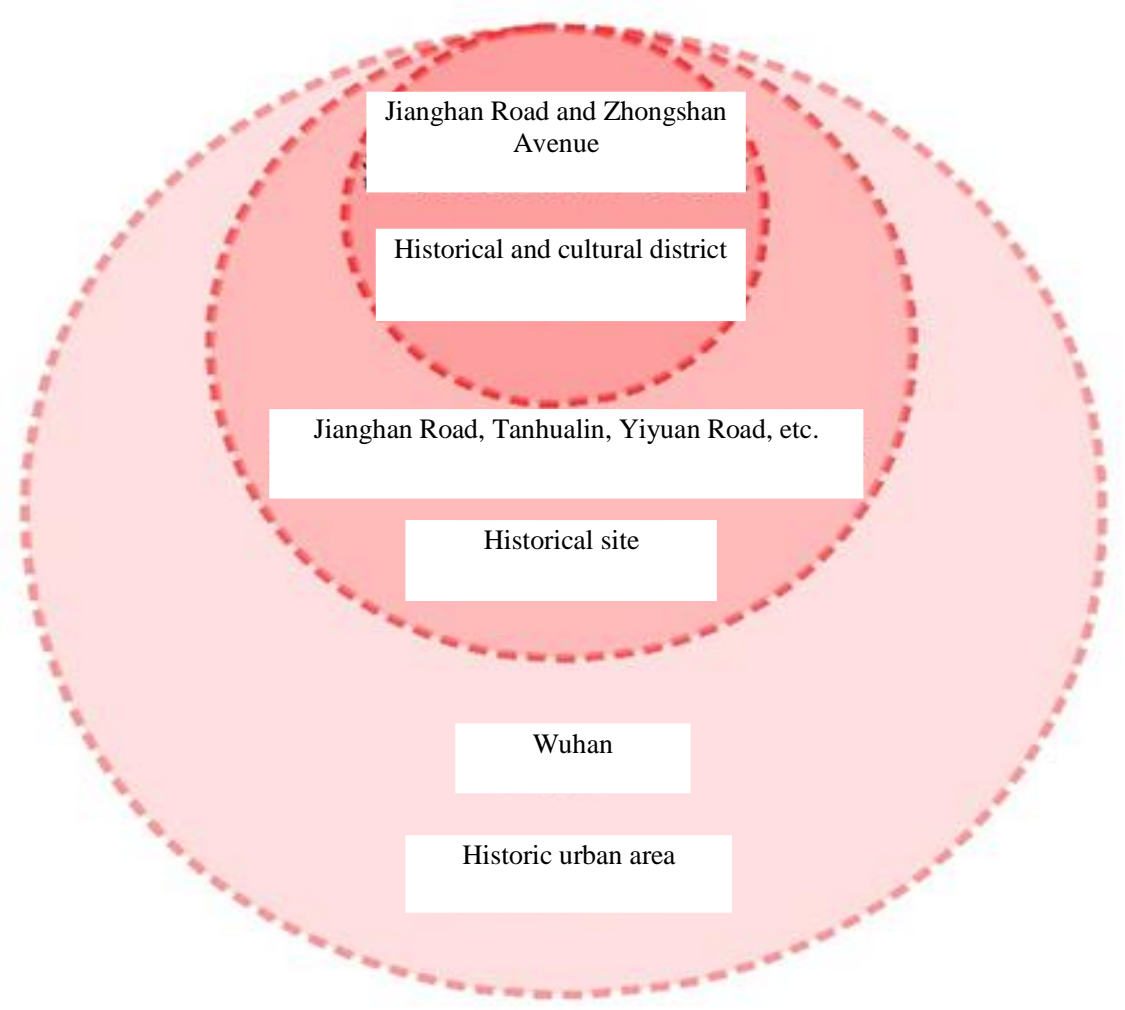

Fig. 1. Analysis of related concepts of historical and cultural blocks - taking Wuhan as an example.

2) The origin and legal regulations of the preservation and reformation of Chinese and European historical and cultural blocks: The State Council of the People's Republic of China promulgated the "Relics Protection Law of the People's Republic of China" in 1982. It first proposed the concept of a historical and cultural protection area, and started the process of the preservation and reformation of historical and cultural blocks with the protection of historical cities as the main line.

Unlike China, many European countries have conducted in-depth research on the protection planning of urban historical and cultural blocks in 1960. France put forward the concept of protected areas in the "Malraux Decree" of 1962. Other developed countries have also developed their own theoretical and technical systems of historical and cultural block protection planning. ("Table I") Today, the basic concepts, theories and principles concerning the protection of historical blocks have been formed internationally.

\section{B. Research purpose and significance}

A well-preserved historical and cultural block symbolizes the historical and cultural look of a city. In recent years, with the steady development of urban modernization, the preservation and reformation of historical and cultural blocks in China and foreign countries have attracted the attention of the people and the government. Only by formulating a standardized and effective protection and transformation plan and adopting a scientific protection and transformation mechanism can historical and cultural blocks be reasonably and effectively protected.

Different countries, cultures, and religious beliefs affect the local historical buildings and blocks, so China and Europe will produce different historical and cultural block protection concepts and restoration techniques. From the perspective of analysis and comparison, the protection concept and technology of Jianghan Road in Wuhan and Marais District in Paris are explored, the reasons for the differences in the protection and transformation of historical and cultural blocks in China and Europe are revealed, and the future development direction is explored in combination with their advantages and disadvantages. 
TABLE I. LIST OF RELEVANT LAWS AND REGULATIONS OF CHINESE AND FRENCH HISTORICAL AND CULTURAL BLOCKS

\begin{tabular}{|c|c|c|c|c|}
\hline Country & Related laws & Legislative time & Proposed concept & Details \\
\hline \multirow{3}{*}{ China } & $\begin{array}{l}\text { "Relics Protection Law of } \\
\text { the People's Republic of } \\
\text { China" }\end{array}$ & $\begin{array}{l}\text { November } 19, \\
1982\end{array}$ & $\begin{array}{l}\text { Historical and cultural } \\
\text { protection area }\end{array}$ & $\begin{array}{l}\text { Blocks, building groups, towns, villages } \\
\text { where cultural relics and historical sites } \\
\text { are concentrated, or that can more fully } \\
\text { reflect the traditional features and local } \\
\text { characteristics of a certain historical } \\
\text { period }\end{array}$ \\
\hline & $\begin{array}{l}\text { "Relics Protection Law of } \\
\text { the People's Republic of } \\
\text { China" (Revision 02) }\end{array}$ & October 28, 2002 & $\begin{array}{l}\text { Historical and cultural } \\
\text { blocks }\end{array}$ & $\begin{array}{l}\text { The historical areas that should be } \\
\text { protected under the approval of the } \\
\text { people's governments of provinces, } \\
\text { autonomous regions and municipalities } \\
\text { directly under the central government }\end{array}$ \\
\hline & $\begin{array}{l}\text { "Regulations on the } \\
\text { Protection of Historical } \\
\text { and Cultural Cities, } \\
\text { Famous Towns and } \\
\text { Famous Villages" }\end{array}$ & July 1, 2008 & $\begin{array}{l}\text { Historical and cultural } \\
\text { blocks }\end{array}$ & $\begin{array}{l}\text { Regions with a certain scale that are } \\
\text { preserved and approved by the people's } \\
\text { governments of provinces, autonomous } \\
\text { regions, and municipalities directly under } \\
\text { the central government, which are } \\
\text { particularly rich in preserved cultural } \\
\text { relics, concentrated in historical buildings, } \\
\text { and can reflect the traditional pattern and } \\
\text { historical features more completely and } \\
\text { truly }\end{array}$ \\
\hline \multirow{3}{*}{ France } & "Malraux Decree" & August 4, 1962 & $\begin{array}{l}\text { Protected area (secteu rs } \\
\text { sauvegardés) }\end{array}$ & $\begin{array}{l}\text { Areas that reflect historical or aesthetic } \\
\text { characteristics or are essentially sufficient } \\
\text { to protect, restore, and recreate the value } \\
\text { of the whole or part of the building groups }\end{array}$ \\
\hline & "Decentralization Law" & January 7, 1983 & $\begin{array}{l}\text { Architectural, Urban and } \\
\text { Landscape Heritage } \\
\text { Protection (ZPPAUP) }\end{array}$ & $\begin{array}{l}\text { The protection of the value of } \\
\text { architectural, historical, legacy or } \\
\text { landscapes in areas or blocks that need to } \\
\text { be protected is the primary consideration } \\
\text { for determining the scope of the protection } \\
\text { area. On the one hand, it replaces the } \\
\text { original 500m radius protection area } \\
\text { around the historical buildings, on the } \\
\text { other hand it also includes other } \\
\text { distinctive heritage }\end{array}$ \\
\hline & "The Heritage Code" & $\begin{array}{l}\text { September } \\
2004\end{array}$ & $\begin{array}{l}\text { Historical monument } \\
\text { (monument historique) }\end{array}$ & $\begin{array}{l}\text { Refers to areas with cultural, architectural, } \\
\text { urban, landscape, historical, or } \\
\text { archeological benefits, which can promote } \\
\text { the development and utilization of built } \\
\text { environmental historical heritage and } \\
\text { space, while respecting the principle of } \\
\text { sustainable development }\end{array}$ \\
\hline
\end{tabular}

a. Source: "Compilation and Management of the Protection Planning of Historical and Cultural Areas"

\section{COMPARATIVE STUDY OF THE}

\section{DEVELOPMENT OF THE PLANNING SYSTEM FOR HISTORICAL AND CULTURAL BLOCKS IN CHINA AND EUROPE}

\section{A. The history of the preservation and reformation of the historical and cultural blocks in China and Europe}

\section{1) Differences in the legislative system}

a) China: Since the founding of New China in 1949, China's protection system for historical and cultural heritage has gradually improved; the provisions of the scope, protection methods, administrative procedures, and legal responsibilities of historical and cultural blocks are mainly derived from the "Relics Protection Law of the People's Republic of China" (2002 Revised Edition) and the "Regulations on the Protection of Historical and Cultural Cities, Famous Towns and Famous Villages"; and the protection and transformation planning of historical and cultural blocks is stipulated by the "Standard for the Protection and Planning of Historical and Cultural Cities".

b) France: The core of the protection system of French historical and cultural blocks is the national government legislation, on this basis, more detailed protection methods, legal provisions and funding policies have been formulated. The French local government is mainly responsible for the implementation and interpretation of legal provisions, and provides protection planning recommendations for 
residents. At the same time, it makes limited supplements and deepening of national legislation through the formulation of local planning and regulatory documents. The most notable feature is the integration of protection organizations' supervision and legislative participation into the legislative and enforcement procedures.

2) History of theoretical development: The preservation and reformation of European historical and cultural blocks first appeared in the Italian Renaissance period, and gradually developed and matured after many movements; while the preservation and reformation of historical block protection in China started late. China's protection planning theory mainly draws on mature foreign theories, and combines with excellent foreign protection theories to derive some theories with local characteristics such as urban organic renewal. On the basis of sustainable development, China continuously improve the quality of urban planning and integrate the historical buildings in the historical and cultural blocks with the surrounding environment.

During the renovation of Bologna, Italy in 1970, a new point of view was put forward - the principle of "integrated preservation", which not only included the environmental protection of buildings left over from history, but also the protection of their culture. Until the 1990s, after the State Council of China also recognized the principle of "integrated preservation", the protection theory of China's historical and cultural blocks began to be consistent with the mainstream protection and transformation theory in the West. The concept of "integrated preservation" has gradually matured in the practical exploration of China and the West.

\section{B. Comparison of work operation system for the preservation and reformation of historical and cultural blocks}

1) The differences between formulating protection plans and protection methods: The protection and reconstruction of China's historical and cultural blocks is a separate management and protection system between the state and local areas; the protection of historical and cultural blocks is jointly undertaken by the cultural relics department and the construction planning department, that is, in the central government, the State Administration of Cultural Heritage and the Ministry of Construction are responsible, while in the localities, the Ministry of Urban Construction Planning and the Department of Cultural Relics are jointly responsible.
France adopts a central power management model. There are special departments and heritage departments responsible for major decisions on historic and cultural buildings and urban cultural heritage. The national historical and cultural heritage protection related work and review are the responsibility of the French National Architect (ABF), and local engineering projects can only be carried out after approval by the national architect.("Table II") 
TABLE II. LIST OF PLANS AND METHODS FOR THE PROTECTION AND RECONSTRUCTION OF CHINESE AND FRENCH HISTORICAL AND CULTURAL BLOCKS

\begin{tabular}{|c|c|c|}
\hline Country & China & France \\
\hline $\begin{array}{c}\text { Protective planning } \\
\text { content }\end{array}$ & $\begin{array}{l}\text { 1. Determining protection objectives and } \\
\text { principles, protecting historical features, } \\
\text { maintaining the overall spatial scale, and putting } \\
\text { forward specific protection requirements for streets } \\
\text { and surrounding landscapes } \\
\text { 2. Drawing protection boundaries } \\
\text { 3. Proposing regulations on maintenance, } \\
\text { improvement and remediation of buildings and } \\
\text { historical environmental elements } \\
\text { 4. Surveying land nature } \\
\text { 5. Regulations on height control of institutional } \\
\text { buildings } \\
\text { 6. Renovation planning and design of important } \\
\text { nodes } \\
\text { 7. Formulating and implementing management } \\
\text { measures } \\
\text { 8. Road Traffic Planning } \\
\text { 9. Municipal Engineering Planning } \\
\text { 10. Disaster prevention and environmental } \\
\text { protection planning }\end{array}$ & $\begin{array}{l}\text { 1. All documents related to the city } \\
\text { 2. The status quo of the area, the status quo of cultural } \\
\text { relics and the expert judgment, archaeological discoveries } \\
\text { and the status quo of urban space } \\
\text { 3. Arrangement of historical protected areas in terms of } \\
\text { population and social development, housing conditions, } \\
\text { and economic activities. Such as the status quo analysis } \\
\text { and future expectations of public facilities, traffic, } \\
\text { transportation, stations, sidewalks, etc. } \\
\text { 4. Urban citizen policy and the goal and direction of urban } \\
\text { historical heritage protection } \\
\text { 5. Measures to treat cultural relics and protect public } \\
\text { spaces } \\
6 \text {. Methods of decision-making, implementation and } \\
\text { financial assistance } \\
\text { 7. Coordination with relevant documents of urban } \\
\text { development and coordination with relevant urban } \\
\text { planning laws and regulations } \\
\text { 8. Development plan for regional residence and publicity } \\
\text { plan for document publication }\end{array}$ \\
\hline $\begin{array}{c}\text { Protective planning } \\
\text { method }\end{array}$ & $\begin{array}{l}\text { 1. The appearance, greening layout and plant } \\
\text { configuration of the additional facilities in } \\
\text { historical and cultural blocks should meet the } \\
\text { requirements of historical style } \\
\text { 2. The protection plan should include contents to } \\
\text { improve the living environment of the residents and } \\
\text { maintain the vitality of the blocks } \\
\text { 3. The historical buildings located outside the } \\
\text { historical and cultural blocks should also be } \\
\text { managed in accordance with the protection } \\
\text { requirements of the historical and cultural blocks }\end{array}$ & $\begin{array}{l}\text { 1. Announcement, public reconciliation and voting } \\
\text { 2. Any changes in each building must be approved by the } \\
\text { French national architect } \\
\text { 3. The revised rule document and the opinions of the } \\
\text { national architect and local council will be sent to the } \\
\text { National Committee for Historic Reserves for record. } \\
\text { After approval by the relevant state departments, the } \\
\text { French Senate will finally approve the announcement }\end{array}$ \\
\hline
\end{tabular}

a. Sources: "Compilation and Management of the Protection Planning of Historical and Cultural Areas", "Protection Theory and Planning of Historical and Cultural Cities"

\section{STRATEGY ANALYSIS OF PRESERVATION AND REFORMATION OF MARAIS BLOCK, PARIS}

\section{A. History of the Marais Block}

Paris is a world-famous historical city with more than 1,300 years of history as a capital and more than 2,000 years of history as a city and it is one of the oldest cities in the world; Paris has two protected areas, namely the Seventh District on the left bank of the Seine and Marais District on the right bank. Before the 18 th century, the wealthy merchants and nobles in the Marais District gathered, so a large number of noble residences and villas remained; however, after the 18th century, the Marais District affected by the Industrial Revolution became the main manual workshop area in Paris, and a large number of foreign populations also chose to emigrate here. As a result, the density of the population and buildings in the Marais District was much higher than that of other blocks in Paris. At that time, the Marais District was even classified as an "unhealthy block" in the center of Paris because of the extremely poor hygienic conditions. As a result, after the promulgation of the "Malraux Decree" in 1962, the Marais District became the first legally protected area in France, and most of the historic buildings in the entire block were finally protected and repaired. Then the Marais District has become a famous fashion and leisure center in France. The villas and official mansions of the nobles have been transformed into art galleries, museums or cultural centers.

\section{B. Preservation and reformation strategies and current status of Marais District}

During the implementation of the planning of the Marais protected area, the French government has always insisted on maintaining the diversity of the local population structure. As the entire block is protected and repaired, the price of land and houses after the renovation has soared, resulting in more and more rich and powerful people, and low-income people are inevitably squeezed out of the Marais District. In order to enable the traditional handicraft industry that represents the specialty of the block to survive in the block, the local government implemented the protection zone plan while implementing some policies to encourage handicraftsmen to remain in the block, and used a part of the renovated area as a social residential area, so that the low Income earners can also maintain basic accommodation. 
The French government also bears most of the funds needed for the remediation of the blocks. In the early days of the "Malraux Decree", France first launched a plan called "Implementing Blocks". In order to show that the planning of the protected areas can indeed have a positive effect on the protection and transformation of blocks, the government directly invested a large amount of money in some streets in the Marais District and renovated it in accordance with the planning requirements of the protected area.

\section{HISTORY AND CURRENT STATUS OF HISTORICAL AND CULTURAL BLOCK PROTECTION AND RECONSTRUCTION IN JIANGHAN ROAD, HANKOU}

\section{A. Historical evolution of Jianghan Road}

Wuhan is located at the confluence of the Yangtze River and the Han River, and its geographical position is very superior. During the Qing Dynasty, it was called the first prosperous place in Chuzhong. In the eight years of Xianfeng period in Qing Dynasty, due to the execution of the unequal treaty "Treaty of Tianjin", Hankou was opened as a foreign trade port; after the official port opening of Hankou in 1861, foreign powers invaded, and Britain, Russia, France, Germany, and Japan successively set up concessions in Hankou, which lasted for more than 80 years. During the period of the Republic of China, from the temporary provisional presidential administration in 1912 to the founding of New China in 1949, warlords fought and the ruling class continued to change, which directly led to the emergence of various architectural groups in the Hankou concession.

In January 2015, the Ministry of Housing and Urban-Rural Development and the State Administration of Cultural Heritage announced the 30 blocks of Jianghan Road and Zhongshan Avenue blocks, Wuhan, as well as Beijing Huangcheng Block, Tianjin Five Old Blocks, and Shanghai Bund Block as China's first batch of historical and cultural blocks. Jianghan Road and Zhongshan Avenue blocks are also the first national historical and cultural blocks in Wuhan. The two roads of Jianghan Road and Zhongshan Avenue divide the entire historical and cultural block in a cross shape, presenting the overall layout of "three blocks in two areas and a cross axis"; the north of Jianghan Road is the Wanguo Concession Block, which shows the historical features of the modern concession area, and the south of Jianghan Road is the Huajie District, which carries traditional culture and business characteristics.

\section{B. Current status of historical and cultural blocks in Jianghan Road}

Jianghan Road was awarded the title of "A Street of National Commercial Civilization" in 1985, and has become a well-known commercial street in China and foreign countries for its unique historical culture, architectural style and commercial atmosphere. However, under the temptation of interest, many shops have chosen to demolish the original historical buildings and transform them into modern Jianghan Road walking streets. In the transformation of the historical and cultural blocks of Jianghan Road, people pay too much attention to commercial interests and cause the historical culture of the block to gradually disappear. And over-commercialization causes the block to lose its original historical character.

There was once a Xinhua Bookstore on Jianghan Road known as "Wuhan's oldest Xinhua Bookstore", but this bookstore was completely dismantled and closed down in 2010 in order to cooperate with the subway and Zhongshan Avenue renovation project. In 2016, after the renovation and reinstallation, Xinhua Bookstore has become "out of all recognition", and no trace of historical buildings can be seen at all.

\section{THE DIRECTION OF THE FUTURE TRANSFORMATION OF THE HISTORICAL AND CULTURAL BLOCKS IN JIANGHAN ROAD, HANKOU}

\section{A. Constructing a reasonable protection planning system}

To build a reasonable protection planning system, first of all, it should be based on relevant laws to establish the basis for the protection planning, then make corresponding preliminary research on historical and cultural blocks, and combine the research content with the protection planning. On this basis, some French practices can be learned from to list some blocks with cultural and historical value in the historical city as protected areas to prevent the destruction of historical and cultural blocks in the process of urban development. On the basis of the "urban street's protection for scenery" in the protection of historical and cultural cities in the overall plan, the planning and design for landscapes in the protection of the style of historical blocks should be added, and the facades of historical buildings should be properly retained and placed on the street. It's also necessary to make some sculptures and landscape sketches that can be integrated with historical buildings on the street to form an overall protection of the spatial pattern of historical and cultural blocks, so as to maximize the social benefits of historical and cultural blocks.

\section{B. Improving laws and protection mechanisms}

Experiences from China and foreign countries have shown that the use of detailed technical specification control methods is very effective in the protection and transformation of historical buildings. Some ancient 
buildings and historical and cultural blocks in China have been transformed and updated under the so-called protection theory, but they have lost their original historical features. Continuous demolition will only replace excellent historical buildings, so it is very important to formulate a technical specification for the protection and transformation of historical buildings and historical and cultural blocks, which will also bring its protection and transformation to an operational level.

\section{Protective reuse of historical buildings}

The reuse of historical buildings can effectively stimulate the vitality of historical and cultural blocks. By replacing the functions of historical buildings, the cultural displays of homestays and historical exhibitions of ancient buildings are placed in the blocks to replace the original residential functions, and the literary creation serves as a characteristic of the city's historical and cultural blocks, which not only protects the historical building itself, but also gives the building a new life, realizing the double balance of development and protection.

\section{Improving regional facilities}

In addition to the necessary infrastructure, the public service facilities and cultural facilities should be improved as much as possible in the urban renewal and transformation. Taking Jianghan Road as an example, there are only some modern billboards and a few sculptures reflecting the life of Wuhan people in the block. Therefore, some decorations and sculpture sketches that reflect the historical culture of this street should be added to allow the landscape to integrate perfectly with the historical buildings in the block. In addition, it is also necessary to improve the municipal infrastructure such as water, electricity, natural gas, network, and transportation in the block to ensure the basic living conditions of residents, and to strengthen the matching of public space and public service facilities. It is also recommended to dismantle some dilapidated buildings, lay out urban green space, combine underground space development and arrange parking facilities to improve ground walking conditions.

\section{E. Industrial development model combining regional characteristics and diversity}

Industry is an important promoter of the revival of historical and cultural blocks. A single industrial development model is difficult to promote regional economic development. Therefore, it's needed to pay attention to the linkage with the surrounding industries of the region and insist on the combination of characteristic industries and diversified industries, so that the historical and cultural blocks will maintain youth and vitality, develop unique cultural and creative industries and derive relevant industrial chains to improve the living standards of the residents of the blocks and increase the vitality of the historical and cultural blocks.

\section{CONCLUSION}

During the period of reform and opening up, China attached more importance to economic development than anything else, but its awareness of the protection of historical and cultural blocks became increasingly weak. Today, however, with the rapid development of society, both China and the West have recognized the importance of the protection and transformation of historical and cultural blocks and the value of the protection of historical and cultural blocks. This paper compares and analyzes the protection and reconstruction strategies of historical and cultural blocks between China and France. Both China's shortcomings in the protection and renovation of historical and cultural blocks as well as the advantages of western developed countries in protection and reconstruction can be seen. Only by continuously absorbing the experience and technology of ancient and modern Chinese and foreign historical and cultural blocks protection and transformation, can China do a better job in protecting historical buildings.

\section{References}

[1] Li Chen, Generation, Interpretation and differentiation of related concepts of "historical and cultural blocks" [J], Planner, 2011(4): 100-103 (in Chinese)

[2] Yang Le, Gu Yuan. Summarization of Chinese and international experiences on the construction of legal systems for the protection of historical and cultural heritage [P], Chongqing Urban Planning and Design Research Institute Urban and Rural Development Strategy Institute. 2013 (in Chinese)

[3] Shao Yong, Ruan Yisan. On the construction of the legal system for the protection of historical and cultural heritage - Implications from the development of the French historical and cultural heritage protection system [J]. Urban Planning Journal. 2002(03) (in Chinese)

[4] Wu Jiang, Wang Lin. Compilation and management of the protection planning of historical and cultural areas [M] Shanghai: Tongji University Press, 2007: 3 (in Chinese)

[5] "Records of Hankou Concession" Compilation Committee. Records of Hankou Concession [M]. Wuhan: Wuhan Publishing House, 2003.12. (in Chinese)

[6] APUR. Le plan de sauvegarde et de mise en valeur du Marais. Paris Projet. No.23/24,1983(in French). APUR. The plan to save and enhance the Marais. Paris Project. No. 23/24,1983.

[7] APUR. Plan Local d'Urbanisme de Paris. 2006. (in French). APUR. Local Urban Plan of Paris.

[8] PLU de Paris.2006 (in French). PLU of Paris. 